\title{
Relations between the inflow of foreign direct investments and economic indicators in OECD countries
}

\author{
Ladislav SUHÁNYI ${ }^{1}$, Alžbeta SUHÁNYIOVÁ2, Jaroslav KOREČKO ${ }^{3}$, Lucia \\ BEDNÁROVÁ ${ }^{4 *}$, Jaroslava KÁDÁROVÁ, Hamdi DERKA WI ${ }^{6}$ and Kamila BAČOVÁ
}

\author{
Authors' affiliations and addresses: \\ ${ }^{1,3}$ University of Prešov, Faculty of Management \\ and Business, Konštantínova 16, 08001 Prešov, \\ Slovakia \\ e-mail: ladislav.suhanyi@unipo.sk \\ e-mail: jaroslav.korecko@unipo.sk \\ 2,5 Technical University of Košice, Institute of \\ Industrial Engineering, Management and \\ Environmental Engineering, Letná 9, 04200 \\ Košice, Slovakia \\ e-mail: alzbeta.suhanyiova@tuke.sk \\ e-mail: jaroslava.kadarova@tuke.sk \\ ${ }^{4,6,7}$ Technical University of Košice, Faculty of \\ Mining, Ecology, Process Control and \\ Geotechnologies, Institute of Earth Resources, \\ Letná 9, 04200 Košice, Slovakia \\ e-mail: lucia.bednarova@tuke.sk \\ e-mail: hamdi.derkawi@tuke.sk \\ e-mail: kamila.bacova@tuke.sk \\ *Correspondence: \\ Lucia Bednárová, Technical University of \\ Košice, Institute of Earth Resources, Letná 9, \\ 04200 Košice, Slovakia \\ tel.: +421556022945 \\ e-mail: lucia.bednarova@tuke.sk
}

Acknowledgement:

This paper was supported by research grant VEGA No. 1/0797/20 "Quantification of

Environmental Burden Impacts of the Slovak Regions on Health, Social and Economic System of the Slovak Republic".

How to cite this article:

Suhányi, L., Suhányiová, A., Korečko, J., Bednárová, L., Kádárová, J., Derkawi, H. and Bačová, K. (2021). Relations between the inflow of foreign direct investments and economic indicators in OECD countries. Acta Montanistica Slovaca, Volume 26 (4), 810-824.

DOI:

https://doi.org/10.46544/AMS.v26i4.17

\begin{abstract}
The importance of foreign direct investment in the mining industry can be illustrated in the case of countries whose economy relies heavily on the mining sector as this attracts major foreign investment to them. The aim of the study is to determine whether there is a link between the inflow of foreign direct investment and the selected macroeconomic indicators in OECD countries and to identify groups of countries showing similar characteristics in this context. The evaluation of the interconnection of selected indicators in this study was made firstly by examining if there is a link between the examined macroeconomic indicators (independent variables) and the FDI inflow (dependent variable). The results showed that an increase in labour productivity could be reflected in an increase in FDI inflows. Based on the results obtained, the backward link in relation to labour productivity was also examined, whether there is a link between the macroeconomic indicators (independent variables) and the labour productivity (dependent variable), resulting in that an increase in FDI inflows could translate into an increase in labour productivity. The paper also included cluster analysis, the main goal of which was to determine countries based on the evaluation of labour productivity and the inflow of foreign direct investment. Four clusters have been identified, two large ones and two clusters containing individual countries (Ireland and Luxembourg). All of the V4 countries are included in one of the large clusters, including the countries which are characterised by low variability in average labour productivity and high variability in the average inflow of foreign investment. The mining industry's recommendations, conclusions, and implications are focused mainly on this cluster of countries.
\end{abstract}

\section{Keywords}

Foreign direct investment, labour productivity, economic indicators, OECD countries, clusters. 


\section{Introduction}

Foreign direct investments (FDI) are an integral part of an open and efficient international economic system and a major catalyst for development. At the same time, the benefits of FDIs are not growing automatically and even equally in all countries, sectors or local communities. Attracting FDIs to countries and reaping the full benefits of FDI depends on national policies and the architecture of international investment. This is a challenge, especially for host countries, which need to put in place a clear, broad-based, and efficient environment for investment and for building human and institutional capacity to put it into practice (OECD, 2002).

Theoretical discussions on the impact of foreign direct investments on economic growth date back to the MacDougall (1960) period. In recent years, the impact of FDI in various countries and economies has received a great deal of attention in both theoretical and empirical literature (Inekwe, 2013; Imoudu, 2012; Adams, 2009; Akinlo, 2004).

At the aggregate level, FDI is generally accepted as a key factor supporting economic growth. For example, Han and Wei (2015), who used a regression tree approach with 17 potential regressors for a panel of individual countries, found that foreign direct investment is one of the most important factors in explaining growth performance, especially for middle-income countries.

The inflow of foreign direct investment into the country is supposed to positively affect the development of the gross domestic product, labour productivity, and unemployment rate by creating space for new jobs, new technologies and new production processes, and know-how, contributing to increasing domestic qualification human capital. In the scientific literature can be found a number of analyses of the impact of foreign direct investment on economic indicators, such as gross domestic product, labour productivity, unemployment rate.

\section{Theoretical review}

Foreign direct investment (FDI) is seen as a means of transmitting new ideas, advanced techniques, technologies and skills across borders, creating significant spillover effects (Kumar \& Russel 2002, Campisi et al. 2013).

Motives for foreign direct investments:

- According to the traditional view, the natural (perverse) direction of capital flow is from the rich country to the developing country. The motivation for this is the higher marginal productivity of capital.

- According to eclectic theory (Dunning 1980), the necessary conditions for the realisation of FDI (OLI paradigm) are the following:

- Ownership specific advantages: competitive advantages of the company (e.g. technology, management \& marketing skills, R\&D, company size, etc.),

- Location-specific advantages: e.g. natural resources, cheap labour, state aid, etc.,

- Internalisation advantages: if the benefits of FDI management are higher than licensing, then it is more attractive to perform the value chain activity in-house than to have it performed by an external party,

while in eclectic theory, the underlying motives of FDI include gaining resources, gaining market share, increasing efficiency, and gaining strategic advantage.

The results of various researches and studies point to the positive effect of foreign direct investment on economic growth expressed by the growth of the gross domestic product, on the growth of labour productivity, on the growth of employment, the decline in unemployment, and also on the growth of wages.

This paper focuses on the possible link between FDI and between GDP, wages, employment and labour productivity.

However, research results do not always clearly confirm the mentioned positive effect of FDI. The research of Bačová (2016) showed that in Slovakia in 2009-2015, there was only a small positive association between FDI inflows and between GDP growth, labour productivity growth, employment; a moderate positive association between FDI inflows and the unemployment rate; and a moderate negative association between FDI inflows and the average nominal wage. The effect of FDI on GDP was also examined by Biørn and Han (2017), who found that, in general, a significant positive effect of FDI on GDP could not be demonstrated, but in the case of developing Asian countries, FDI significantly improves GDP growth. Wang and Wei (2017) examined the relationship between exchange rates, economic growth and foreign direct investment. According to their conclusions, economic growth is slowing down due to foreign direct investment, but economic growth will return to its original level in the next period.

In theory, there are several potential ways in which FDI can cause growth (Kosztowniak 2016). Macroeconomic analysis generally supports a positive connection between FDI and growth (Borensztein et al. 1998, Kottaridi et al. 2010), a connection which is further reinforced in countries with a well-developed financial market (Alfaro et al. 2004). The Solow-type standard neoclassical growth models (Solow 1999) suggest that FDI 
increases the capital stock and thus promotes growth in the host economy by financing capital formation (Brems, 1970; Kida, 2014). FDI promotes economic growth with a short run effect by increasing the volume of investment and/or its efficiency (Kosztowniak, 2016).

Overall conclusions presented by the previously mentioned research of the authors Biørn and Han (2017) are: (1) Aggregate FDI has a positive, but insignificant effect on aggregate GDP based on the full country panel; (2) for the developing Asian countries, FDI significantly improves GDP growth; and (3) manufacturing FDI impacts both manufacturing and service GDP growth positively.

The author Kosztowniak (2016) confirmed the bi-directional relationships between FDI and GDP in Poland. However, the impact of GDP on attracting FDI inflows to Poland is stronger than that of FDI on GDP growth. Thus, the Polish developmental policy should concentrate on three essential determinants (pillars) of growth: employment growth, attracting FDI (with emphasis on improvement in the type of inflowing investment), and increasing domestic the value and productivity of domestic investment. According to Kasych (2019), cross-border cooperation within one company can help with company management. In a way, it is also an investment, but it does not have to be just about financial assistance. Kasych and Medvedeva (2019) also add that cross-border transfer of new technologies can also help.

The level of wages is also an indicator that can be in relation to the FDI flow. The study of Halmos (2011) showed positive and significant relations between increasing income inequality and increasing level of FDI in Eastern-European states, although the relation between FDI inflow and GINI index was not demonstrable. The study of Bacovic et al. (2021) revealed that the growth in wages has a negative impact on FDI inflows in the EU countries, but their research also discovered a paradoxical scenario in a specific case of Balkan countries, where increased wages actually have a positive impact on FDI inflows.

The impact of foreign direct investment on overall wages depends not only on how high the foreign firm is. A cross-sectional study by Lipsey and Sjöholm (2004) made on Indonesian manufacturing industries and provinces implies that a higher foreign presence raises the general wage level. The FDI can influence the wage level in different industries. The results of Li et al. (2018) showed that FDI in the generalised virtual economy industry could promote the increase of average wage level in the way that every $1 \%$ increase of FDI increases the average wage level in the industry by $0.88 \%$. From the other perspective, the authors Damijan and Kostevc (2011) examined the role of FDI in the adjustment pattern of regional wages, and the results showed that in most cases, the FDI had contributed significantly to faster adjustment of relative regional wages.

Experience shows that governments worldwide seek to attract foreign direct investments and support them with trade policy incentives, financial assistance and tax incentives (Blomström and Kokko, 2003). One of the important motivations of governments is the assumption that foreign companies stimulate productivity and employment either directly through their own higher productivity and employment growth or through an indirect side effect (Blomström and Kokko, 1998; Görg and Strobl, 2001; Girma, 2005). Inekwe (2013) has conducted a study examining the links between Nigerian employment and foreign direct investment (FDI) in the manufacturing and servicing sectors between 1990 and 2009. Based on the results can be concluded that in that case, FDI in the manufacturing sector has a positive relationship with employment rate while FDI in the servicing sector has a negative relationship with employment rate (in both cases, unidirectional causality from FDI to employment rate was shown). The results are supported by another research of Waldkirch et al. (2009) examining the relation between FDI and employment data in Mexico, which showed that FDI has a significantly positive, though the quantitatively modest impact on manufacturing employment, and they also concluded that the employment enhancing effects of FDI are larger in export-oriented industries. Based on Caves (2007), foreign acquisitions lead to a reduction in labour-use inefficiency, which is consistent with the internalisation theory of FDI, which postulates that multinational firms transfer a range of intangible proprietary assets to their affiliates. This statement is consistent with the empirical estimates of Girma (2005), who, on the other hand, in addition to the long-time effect, also found out that the gain in efficiency is accompanied by negative as well as positive employment effects, suggesting that foreign investments can create as well as destroy jobs in short to medium run. Haskova and Volf (2017) state that foreign direct investment has a positive effect on the employment and GDP of the state, especially in the region in which the investment was made. Therefore, differences are in existence regarding the GDP levels of the regions of the Czech Republic (Civelek et al., 2019). Local currencies might be an effective solution to minimise the inequalities in economic conditions of various geographical regions (Ključnikov et al. 2020a; Ključnikov et al., 2020b; Ključnikov et al., 2020c).

The indications of the literature review led us to examine also labour productivity (for the purposes of this study meaning the share of GDP per employed persons) which was also used by Bacovic et al. (2021) in their study on the determinants of FDI inflows. Technological externalities/spillovers from FDI may increase productivity in general (Lipsey and Sjöholm, 2004), but there are also other studies showing that inflows of FDI might also lead to a lower scale of production and lower productivity in domestic firms (Aitken and Harrison 1999). The study of Bacovic et al. (2021) examined the labour productivity as a determinant of FDI inflows focusing on Balkan countries in comparison with EU countries, and they found out that, in Balkan countries, FDI inflows respond negatively to shocks in labour productivity, which is contrary to the experience of EU countries. 
According to Lavíčková, Kolafová and Turínská (2021), it is possible to increase employee productivity through free language courses paid for by their employer.

\section{Material and Methods}

The aim of the study is to determine whether there is a link between the inflow of foreign direct investment and the selected macroeconomic indicators in OECD countries and to identify groups of countries showing similar characteristics in this context.

The research sample consisted of 36 OECD countries. These are countries that are considered to be more developed countries. The data available from the OECD database for the years 2005-2019 were adjusted and processed to obtain the final indicators described below. US dollars in current PPPs were used for source data in monetary units.

The indicator of employment (EM) was calculated as the number of employed people (not only employees) per 100000 inhabitants. The indicator of labour productivity (LP) was calculated as GDP per employed person. The indicator of average wage (AW) was calculated as a yearly average wage of an individual (single person at $100 \%$ of average gross earnings before taxes with no child). The indicator of GDP was used in absolute numbers per head.

FDI-related indicators can be (Dombi, 2015):

- Flow indicators - the value of a foreign direct investment in a country (FDI imports) or from a country (FDI exports) during a given period

- Stock indicators - the cumulative value of FDI imports and exports up to a given date (imported and exported FDI stocks)

In this paper, for the indicator of foreign direct investments (FDI) the total FDI inward financial flows per head were calculated.

The evaluation of the interconnection of selected indicators in this study was based on the process of validation of the following working hypotheses:

Hypothesis 1: There is a link between the examined macroeconomic indicators (independent variables) and the FDI inflow (dependent variable).

After examining Hypothesis 1 and based on the results obtained, a hypothesis was formulated in order to verify the backward link in relation to labour productivity:

Hypothesis 2: There is a link between the examined macroeconomic indicators (independent variables) and labour productivity (dependent variable).

The proposed "Primary Model of FDI" reflects the relationship between all the mentioned independent variables and the dependent FDI variable. The explanatory macroeconomic variables were employment (EM), average wage (AW), labour productivity (LP) and gross domestic product (GDP) in the OECD countries. The aim of using the regression model was to determine the expected effects of selected explanatory variables on the explained variable. The intention was to find and create the best linear model expressing the dependencies between the selected variables. The model and the expected effects of the explanatory variables on the explained variable were formulated as follows (Meixnerová \& Krajňák, 2020):

$$
\begin{aligned}
& F D I_{t}=f\left(E M_{t}, A W_{t}, L P_{t}, G D P_{t}\right) \\
& F D I_{t}=f(+,-,+,+)
\end{aligned}
$$

The proposed "Primary Model of LP" reflects the between all the following independent variables on the dependent LP variable:

$$
\begin{aligned}
L P_{t} & =f\left(E M_{t}, A W_{t}, F D I_{t}, G D P_{t}\right) \\
L P_{t} & =f(-,+,+,+)
\end{aligned}
$$

All "primary" and "secondary" regression models were tested for the presence of adverse events in the model. The "secondary" regression models were derived from the "primary" regression models replacing the values of the indicators by their differences. The presence of heteroskedasticity was tested by the Breusch-Pagan test, the autocorrelation was verified by the Durbin-Watson test, the presence of multicollinearity was verified by the VIF (variance inflation factor) test. 
The last part of the analysis was devoted to the application of cluster analysis. The main goal was to determine countries based on the evaluation of labour productivity and the inflow of foreign direct investment. Cluster analysis (CLU) is useful in cases where objects have a natural tendency to cluster. The objectives of cluster analysis cannot be separated from searching and selecting the suitable characters to define the clustered objects. The found clusters describe the data structure only with respect to the selected characters (Meloun, 2012). The choice of features of objects must be preceded by an analysis of theoretical and practical criteria for their justification. Therefore, the cluster analysis was preceded by relevant statistical research, even in our case.

The goal of the CLU is to cover a set of objects with their subsets, which may not be disjoint. After identifying significantly different groups of objects, it is possible to concretise them. The groups may differ, for example, by the level of the monitored trait (variable) or its variability (Král', 2009).

Since practical data mining problems high-dimensional data are clustered, the resulting clusters are highdimensional geometrical objects which are difficult to analyse and interpret. A low-dimensional graphical representation of the clusters could be much more informative than such a single value of the cluster validity. One can cluster by eye and qualitatively validate conclusions drawn from clustering algorithms (Abonyi \& Feil, 2007).

In this paper, both hierarchical and non-hierarchical clustering were used.

\section{- $\quad$ Hierarchical clustering}

The most commonly used measure of the distance of objects is the Euclidean distance, respectively geometric distance. The Euclidean distance forms the basis of Ward's clustering method, which have been used in the presented model. This is the so-called divisional clustering, which is based on the set of all objects (countries) as a single cluster and its gradual division leads to a system of clusters. The advantage of hierarchical methods is that it is not necessary to know in advance the number of clusters before the clustering process itself.

Euclidean distance is defined by the formula:

$d_{i j}=\sqrt{\sum_{k=1}^{K}\left(x_{i k}-x_{j k}\right)^{2}}$

Where $x_{i k}$ is the value of $k$ variable for $i$-th object and $x_{j k}$ is the value of $k$ variable for $j$-th object. The rule of linking statistical units into clusters is then determined for calculated distance.

Ward's method is a "procedure for forming hierarchical groups of mutually exclusive subsets on the basis of their similarity with respect to specified characteristics" (Ward, 1963).

The principle of Ward's clustering method is to minimise the heterogeneity of clusters according to the criterion of the minimum increment of the intra-group sum of squares of deviations of objects from the centre of gravity of clusters. If the cluster consists of $j$ objects that are characterised by $m$ characters, a matrix $j$ x $m$ with elements $x_{i k}$ (value of the $k$-th character for the $j$-th object) is available. Within-cluster variability (sum of squares within $\left.-S S_{W}\right)$ is then given by:

$S S_{W}=\sum_{k=1}^{m} \sum_{i=1}^{j}\left(x_{i k}-x_{k}^{-}\right)^{2}$

while

$x_{k}^{-}=\frac{1}{j} \sum_{i=1}^{j} x_{i k}$

Adding more clusters with $j_{l}$ objects increases the number of rows of the original matrix to $j+j_{l}$, and $S S_{W}$ counts for a larger number of objects.

- Non-hierarchical clustering

Non-hierarchical methods use the optimisation procedure, where it happens that during the formation of clusters, an object (country) is closer or further away from the cluster in which it is currently located. Then the optimisation procedure places it in another (closer) cluster. A key problem with non-hierarchical methods is the choice of the number of clusters in advance. For this reason, hierarchical clustering was first carried out in this research, which indicated the number of clusters in the set of surveyed countries. The same number was used in this case as well. Later, this number was optimised according to the position of the objects.

In the subsequent clustering process, the K-means method was used, which consists in dividing $n$ objects with $m$ characters into $k$ clusters so that the between-cluster sum of squares (sum of squares between $-S S_{B}$ ) is minimised.

$S S_{B}=\frac{n m}{n m-m} \sum_{l=1}^{k} \sum_{i=1}^{m} \sum_{j=1}^{n_{k}}\left(1-\delta_{i j l}\right)\left(y_{i j}-c_{i l}\right)^{2}$ 
It is assumed that $n$ objects are divided into $k$ clusters. Then the $k$-th cluster contains $n_{k}$ objects. Each object is described by $m$ characters. The missing value of the $i$-th character in the $j$-th line and in the $k$-th cluster is denoted as $\delta_{i j k}$. The $x_{i j}$ data are pre-standardised and denoted as $y_{i j}$. The value of $c_{i k}$ is the mean value (average) of the $i$-th character in the $k$-th cluster (Meloun, 2012).

\section{Results}

As mentioned above, we will present the implementation and results of stepwise regression in the following section. The estimated vectors of regression coefficients in the model generate the influence of the explanatory variables on the explained variable at the significance level $\alpha$. The performed test of statistical significance of variables determined which explanatory variables we will consider as significant determinants of FDI and LP. The above facts illustrate the following outputs:

Tab. 1. Estimation of regression coefficients in Primary Model of FDI

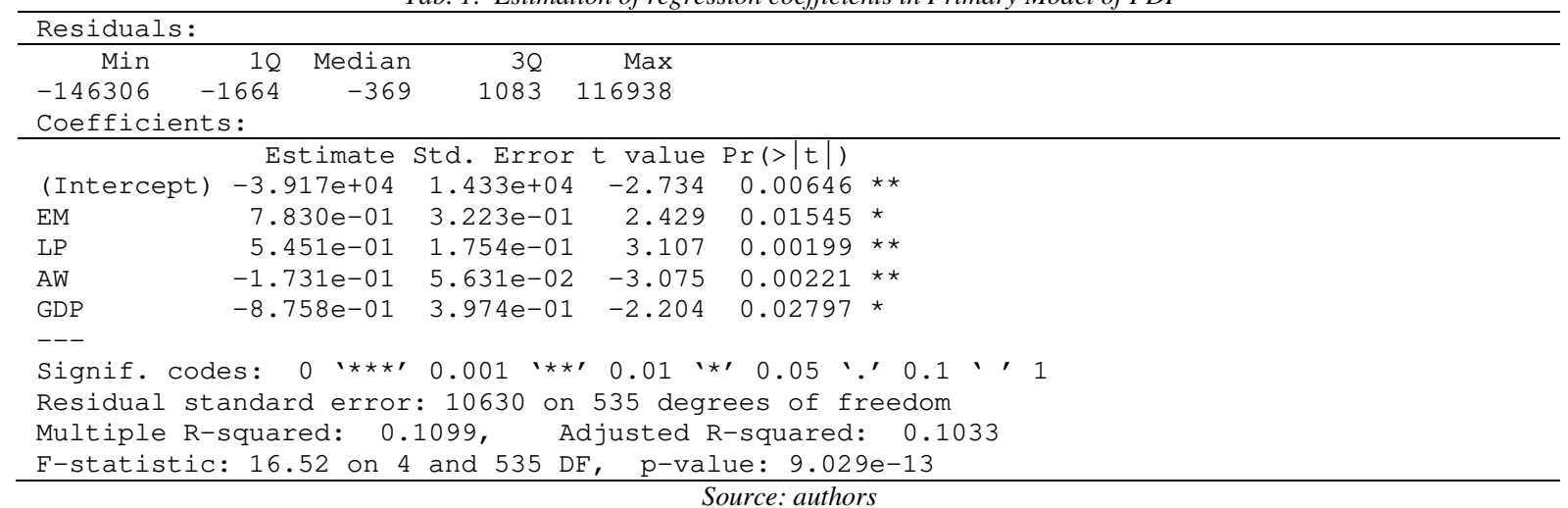

Testing the "Primary Model of FDI" showed that this regression model was burdened by heteroskedasticity and autocorrelation of variables (Table 1). Due to the requirement to remove undesirable phenomena from the original model, the variables in the "Secondary Model of FDI" have therefore been replaced by their differences.

Tab. 2. Final estimation of regression coefficients in Secondary Model of FDI

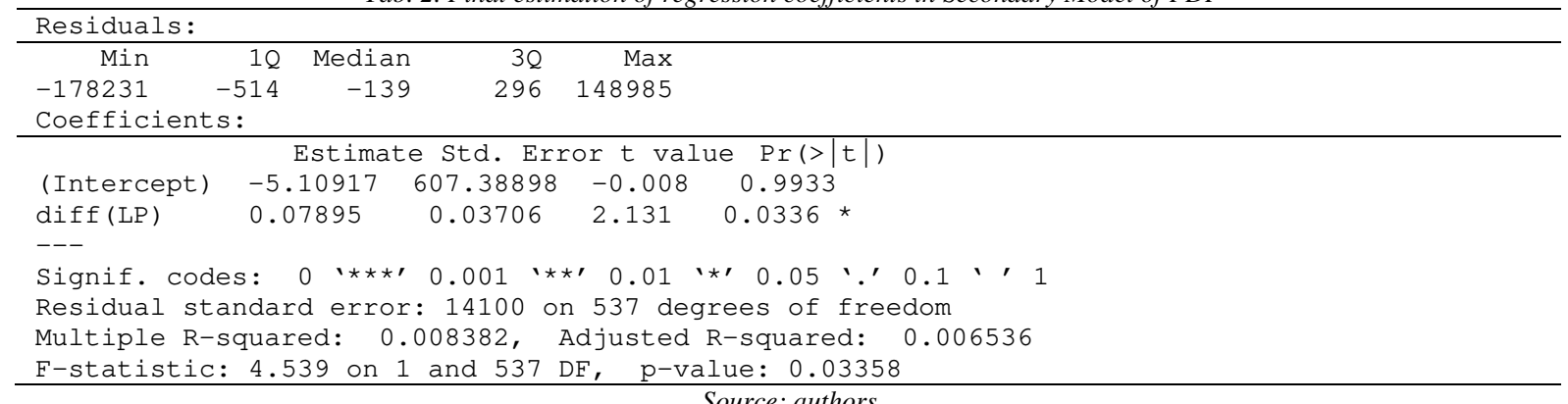

Based on the testing, exogenous variables were removed from the "Secondary Model of FDI", which showed statistical insignificance according to the achieved $t$-values. Low $t$-values indicated a weak explanatory power of the coefficient of the given variable. According to the model, the variable AW is statistically insignificant. In other modifications of the model, this variable was disregarded. In the "Secondary Model of FDI", the variables had a normal distribution, but the multicollinearity test showed its presence in the model. Naturally, the pairs of variables GDP and LP, as well as the EM and LP, show a high degree of mutual correlation. Based on their mutual correlation, it was possible to omit these variables. According to the estimators and $t$-values in the model, it was optimal to omit GDP and EM first. The final estimation of regression coefficients at the significance level $\alpha=0.05$ shows that if the labour productivity in OECD countries increases by one unit, the foreign investment flows will increase by 0.07895 units (Table 2). This result cannot be quantified in this way entirely, but it appears that there is a link between FDI flows and labour productivity that needs to be taken into account in decision-making. Thus, based on the findings, an increase in labour productivity could be reflected in an increase in FDI inflows. 
Tab. 3. Estimation of regression coefficients in Primary Model of $L P$

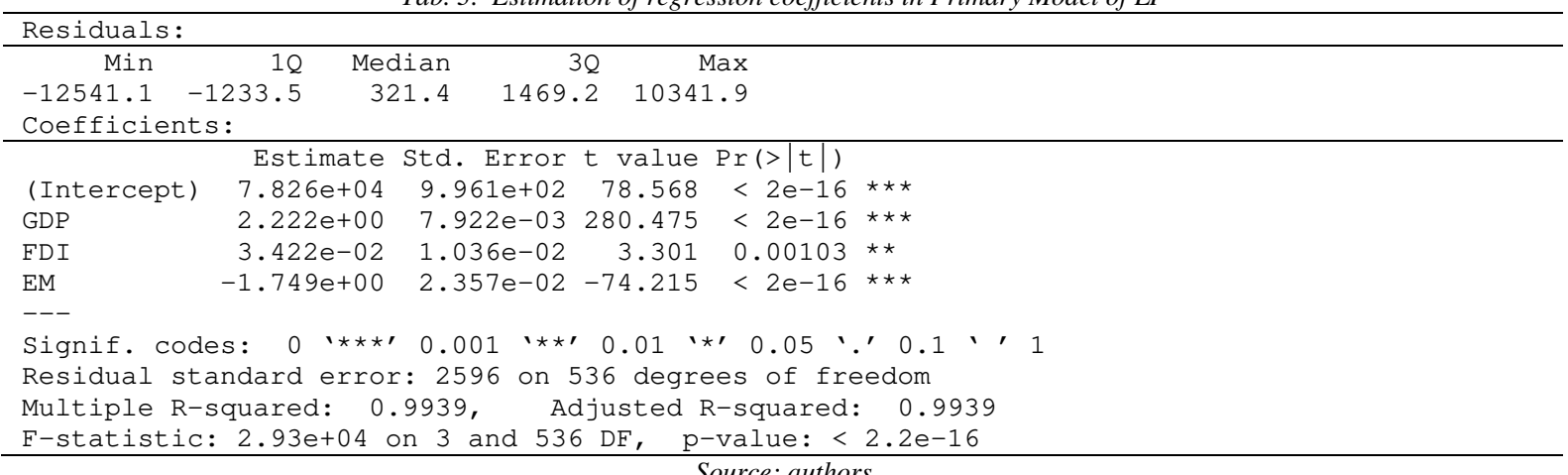

The variable AW, which turned out to be statistically insignificant, was initially removed from the "Primary Model of LP". Testing showed that this regression model was also burdened by heteroskedasticity and autocorrelation of variables (Table 3). The elimination of undesirable phenomena from the original model required the replacement of the original variables by their differences in the "Secondary Model of LP".

Tab. 4. Final estimation of regression coefficients in Secondary Model of LP

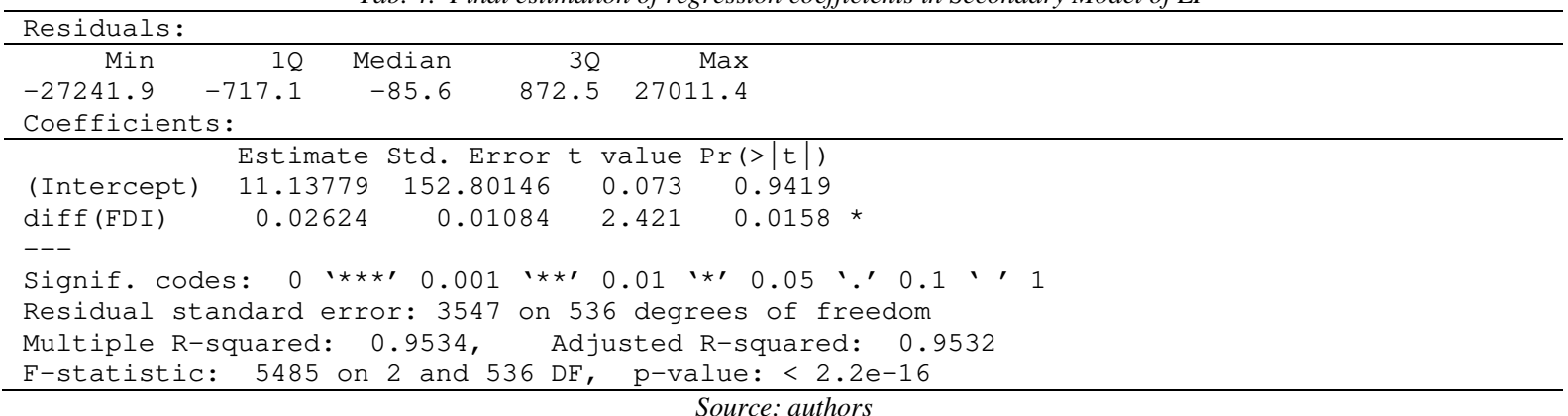

By the step-by-step testing of the "Secondary Model of LP" the exogenous variables were removed, which according to the achieved $t$-values, showed statistical insignificance. According to the model, the variable AW is statistically insignificant. In the following modifications of the model, it was also abstracted from other variables that showed mutual multicollinearity. The final estimation of the regression coefficients at the level of significance $\alpha=0.05$ shows that if the inflow of foreign investment in OECD countries increases by one unit (dollar), labour productivity will increase by 0.02624 units (Table 4). Again, analogous as in the case of the "Secondary Model of FDI", this result cannot be quantified entirely in this way, but it shows that there is also this opposite link between FDI flow and labour productivity compared to the previous results. That is also an important result that needs to be taken into account in decision-making processes. Based on the findings, an increase in FDI inflows could translate into an increase in labour productivity.

In the next step, the results of the cluster analysis will be presented.

Hierarchical methods are based on the sequentially joining of clusters; their number decreases continuously until finally all clusters are combined into one. Wards method involves an agglomerative clustering algorithm. It looks for groups of leaves that form into branches, the branches into limbs and eventually into the trunk. Ward's method starts out with $n$ clusters of size 1 and continues until all the observations are included in one cluster.

There were $j$ objects in the analysed group, namely 36 OECD countries, in which were pursued $k$ quantitative characters (2 variables - FDI and LP). 


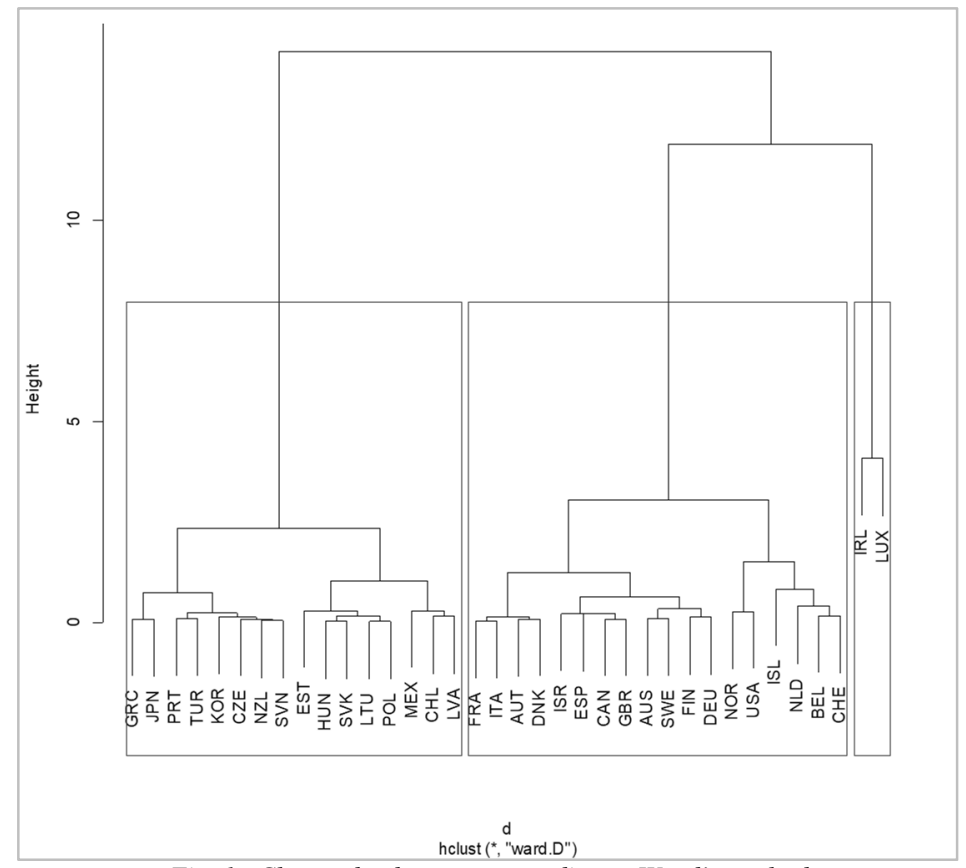

Fig. 1. Cluster dendrogram according to Ward's method Source: authors

In the dendrogram, we can identify three groups of countries with similar characteristics. The groups are highlighted. There are two larger clusters with 16 or 18 countries. Outside of these clusters remained only Ireland and Luxembourg (Figure 1). To draw conclusions that consider the exact distances, we have also used a nonhierarchical clustering method, which is a scatterplot.

If we consider two variables (components), clusters can be visualised by using the non-hierarchical method K-means. Based on the previous hierarchical method, it is considered a similar number of clusters. Kmeans clustering is the most popular partitioning method. It requires the analyst to specify the number of clusters to extract. There are two components which explain $100 \%$ of the point variability.

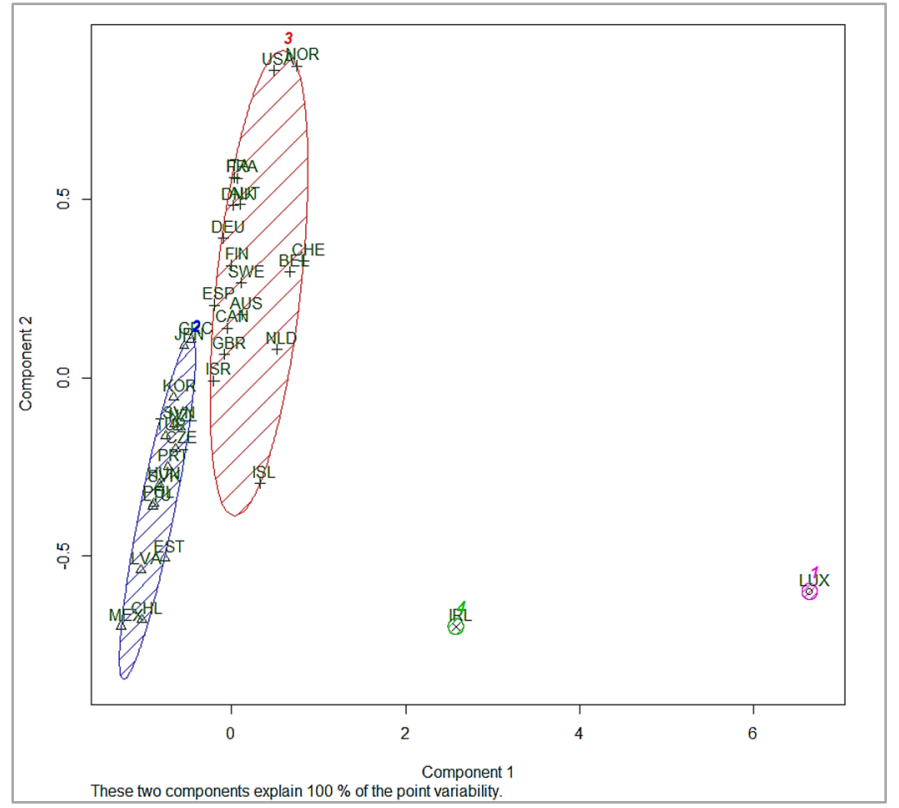

Fig. 2. Scatterplot according to K-means method Source: authors

Due to testing, we have finally chosen 4 clusters as an imputed command for K-means clustering. We consider the data set, which contains 36 objects, and partition it into $k=4$ clusters. The ellipses are based on the average and the covariance matrix of each cluster, and their size is such that they contain all the points of their cluster. The 
ellipses sizes of clusters 2 and 3 are very similar. Cluster no. 3 displays more variability of Component 1 . The larger shading intensity indicates the largest density of divided objects in the ellipse (Figure 2).

Clusters 2 and 3 show approximately the same variability of Component 2 (average FDI inflow). Cluster number 3 is characterised by a higher average level of both Component 2 and Component 1 (average labour productivity). Another interesting result from the regional perspective of the country of origin of the authors of this study is that all the V4 countries are situated in cluster number 2, which is characterised by low variability in average labour productivity and high variability in the average inflow of foreign investment. Outside the clusters, there are two countries, Ireland and Luxembourg, which have been separated on the basis of monitoring their mutual distance in the scatter plot (the final order was finally 4 clusters for non-hierarchical clustering).

By standardising the values of the variables of the examined objects (standardisation of FDI and LP on the scale from -1 to 1), the difference of scales of variables between the countries was eliminated in the cluster analysis. This was done because variables with a greater degree of variability have a greater impact on the resulting degree of similarity. The following Table 5 shows the selected statistics on graphically represented clusters in the scatterplot.

Tab. 5. Selected statistical indicators of $K$-means clustering

\begin{tabular}{|c|c|c|c|}
\hline \multirow[t]{2}{*}{$\begin{array}{l}\text { Members of Cluster } \\
\text { no. } 2 \text { ( } 16 \text { cases) }\end{array}$} & $\begin{aligned} \operatorname{Mean}_{(L P)} & =-0.755167 \\
\operatorname{Mean}_{(F D I)} & =-0.359110 \\
\operatorname{STD}_{(L P)} & =0.308694 \\
\operatorname{STD}_{(F D)} & =0.067042\end{aligned}$ & \multirow[t]{2}{*}{$\begin{array}{l}\text { Members of Cluster } \\
\text { no. } 3 \text { (18 cases) }\end{array}$} & $\begin{aligned} \operatorname{Mean}_{(\mathrm{LP})} & =0.360167 \\
\operatorname{Mean}_{(\mathrm{FDI})} & =-0.093690 \\
\mathrm{STD}_{(\mathrm{LP})} & =0.351917 \\
\mathrm{STD}_{(\mathrm{FDI})} & =0.261551\end{aligned}$ \\
\hline & Distance & & Distance \\
\hline Chile & 0.329180 & Australia & 0.112971 \\
\hline Czech Republic & 0.120999 & Austria & 0.132875 \\
\hline Estonia & 0.160501 & Belgium & 0.341244 \\
\hline Greece & 0.357868 & Canada & 0.212411 \\
\hline Hungary & 0.031410 & Denmark & 0.166381 \\
\hline Japan & 0.313581 & Finland & 0.133501 \\
\hline Korea & 0.182265 & France & 0.190870 \\
\hline Latvia & 0.254653 & Germany & 0.208557 \\
\hline Lithuania & 0.099440 & Iceland & 0.447091 \\
\hline Mexico & 0.447491 & Israel & 0.361206 \\
\hline New Zealand & 0.159146 & Italy & 0.203389 \\
\hline Poland & 0.089628 & Netherlands & 0.289033 \\
\hline Portugal & 0.047284 & Norway & 0.557887 \\
\hline Slovak Republic & 0.035094 & Spain & 0.286717 \\
\hline Slovenia & 0.140835 & Sweden & 0.064818 \\
\hline \multirow[t]{3}{*}{ Turkey } & 0.085915 & Switzerland & 0.451001 \\
\hline & & United Kingdom & 0.263845 \\
\hline & & United States & 0.436828 \\
\hline \multirow[t]{2}{*}{$\begin{array}{l}\text { Members of Cluster } \\
\text { no. } 4\end{array}$} & $\begin{aligned} \operatorname{Mean}_{((\mathrm{LP})} & =1.328820 \\
\operatorname{Mean}_{(\mathrm{FD}))} & =2.314378\end{aligned}$ & \multirow[t]{2}{*}{$\begin{array}{l}\text { Members of Cluster } \\
\text { no. } 1\end{array}$} & $\begin{aligned} \operatorname{Mean}_{(L P)} & =4.270842 \\
M^{\prime} & =5.117805\end{aligned}$ \\
\hline & Distance & & Distance \\
\hline Ireland & 0.00 & Luxembourg & 0.00 \\
\hline
\end{tabular}

The significance of each variable at the significance level $\alpha=0.05$ was confirmed by one-way analysis of variance ( $\mathrm{p}$-value $=0.00000$ ). The between-cluster variability $\left(S S_{B}\right)$ of the LP variable is 31.465 . In the case of FDI it is 33.769 . The within-cluster variability $\left(S S_{W}\right)$ of the LP is 3.534. In the case of FDI it is 1.230.

In each of the four clusters in the table, the "centre points" of the individual variables are presented as a first, represented by the mean values (averages) of the variables and the standard deviations of the variables for the characteristics of the individual clusters. Subsequently, the countries belonging to the individual clusters and their distances from the centre point of the cluster are listed. The largest distance from the centre point in cluster no. 2 has Mexico and Chile, in cluster no. 3 it is Norway and Iceland. Significant distances of these countries from the centre points of the cluster can be clearly seen in the previous graphic presentation in the scatter plot (Figure 2), where these countries are located at the edges of the clusters and thus increase the size of the depicted ellipses. At the same time, they increase the variability of the cluster in terms of the examined variables (components). The 
centre points (averages) in the case of Ireland and Luxembourg differ significantly from the centre points of larger clusters; thus, separate clusters were created represented by their position in the scatterplot.

\section{Discussion}

The aim of the guest country's foreign direct investment in the host country is to increase productivity through technology transfer. On the one hand, it can have positive external effects through business relationships on the other hand (e.g., market access, improving financing conditions) and through them can be boosted economic growth. In general, two main groups of theories can be used to explain why firms engage in foreign direct investment in other countries (Firth, 1980). The first deals with attempts to maximise revenue and asset growth (Shleifer \& Vishny 1989, Morck 1990, Brandenburger \& Polak 1996). The second general group of theories focuses on the motivations for maximising value. These motivations can be financial (cash transfer), or they can be linked to synergies related to economies of scale, to efficiency gains, to gain a monopoly position (Stigler 1964, Capron \& Mitchell 1998) and to efforts to strengthen managerial control over financial resources (Jensen 1988). Boghean \& State (2015) argue that the effects of foreign direct investment (FDI) on the economies of host countries are mainly related to increasing labour productivity through technology transfer, management and marketing capabilities that enable long-term technological progress and economic growth.

Investors look for countries for their investments in which they see the maximisation of benefits for their activities. On the example of V4 countries (Czech Republic, Hungary, Poland, Slovakia), which are also part of this study. Many studies from various disciplines analyze V4 market (Kolková \& Ključnikov 2021, Žufan et al. 2020, Virglerova et al. 2020, Durda \& Ključnikov 2019, Ključnikov et al. 2019). But this paper differs from these studies because it focuses on foreign direct investment inflows and the selected macroeconomic indicators in OECD countries, including V4 countries. It can be seen that after their accession to the European Union, differences in investment incentives (state aid) between member countries have decreased because of the regulations, regional competition in investment incentives has weakened. However, there is still a struggle between countries about FDI. SMEs in those countries have also been negatively affected by this fact due to facing financial problems (Civelek et al. 2020, Civelek et al. 2021, Ključnikov et al. 2021).

The first interesting result of this study is that the results of the analysis show that it is possible to talk about the link between labour productivity and the inflow of foreign direct investment in the direction from labour productivity to FDI inflow, which is in line with various findings of the authors mentioned in this study. Labour productivity in the context of this contribution contains two macroeconomic indicators (employment and GDP). It must be borne in mind that also these two macroeconomic indicators can be linked. Among economists, the "rule of thumb" was used in the pre-crisis period (before 2009) that at least 3\% of GDP growth was needed for employment growth. The impact of the global economic crisis on maintaining employment shoved that it would be enough $1.5 \%$ of GDP growth instead of $3 \%$. However, employment can be negatively affected by growing global insecurity and wages in a short-term perspective. The results of this study show that the growth of the inflow of foreign direct investment can also contribute to a higher level of labour productivity, and thus there can be a larger share of the country's GDP per person employed. This may be because if the investor is looking for opportunities to place his investment plans, he will prefer countries where the employed person is expected to produce higher added value than in the case of another investment alternative.

In view of the above findings, the article also examined the possible link between macroeconomic indicators, to which the FDI inflow indicator was added, and between the labour productivity itself (as a dependent variable). In this regard, a possible link between FDI inflow and labour productivity has been demonstrated, where it appears that even higher FDI inflow can contribute to higher labour productivity in OECD countries, which on the one hand is not in line with the findings of some of the mentioned authors, but on the other, it supports the findings of the authors as, e.g. Piscitello and Rabbiosi (2005). According to them, the impact of foreign direct investments that are realised, for example, through the acquisition of target companies, can be measured by labour productivity. Relying on the idea that multinational companies act as a means of transferring assets, which makes subsidiaries outperform the performance of their competitors in the host countries. The results of Piscitello and Rabbiosi (2005) show that foreign direct investment generally increases the labour productivity of local target companies in the medium term. Their empirical evidence concerned foreign acquisitions that took place in Italy between 1994 and 1997. The findings of this research may also result from the fact that the inflow of foreign direct investment can create new jobs on the one hand, but at the same time, it can boost and streamline the labour market, and on the other hand, it can contribute to some extent to GDP growth itself. Př́vara (2021) and Přívara et al. (2020) have also offered interesting insights into the labour market. The IBM-PLI Global Location Trends 2019 study also talks about job creation. When looking at the countries of V4, it can be seen that in terms of the number of jobs created through FDI, Hungary ranked $16^{\text {th }}$ in the world in 2018, while on the basis of data per million inhabitants, it ranked $5^{\text {th }}$, the Czech Republic $14^{\text {th }}$, Slovakia $15^{\text {th }}$ and Poland in $19^{\text {th }}$ place (IBM Institute for Business Value 2019). Apart from Hungary and Poland, the placement of the other two V4 countries deteriorated compared to the period of 2013-2017, in which Hungary was placed $5^{\text {th }}$ and Poland $25^{\text {th }}$, the Czech Republic $9^{\text {th }}$, and Slovakia $6^{\text {th }}$. 
Of the almost two hundred countries evaluated in the world, only Belgium, Luxembourg, Sweden, and Denmark are ahead of Hungary.

\section{Conclusions and implications for the mining industry}

The importance of foreign direct investment in the mining industry can be illustrated in the case of Guinea, whose economy relies heavily on the mining sector, as this attracts major foreign investment. As it can be seen from the research of Chin (2016), FDI improves efficiency in the mining sector. She concluded that if Guinea wants to increase the mining production, it is imperative to develop effective FDI policies. The research within this study showed that there might be a link between the FDI inflow and the labour productivity in both directions, this is why also the mining industry should count on the possibility that attracting or increasing the foreign direct investments should affect the labour productivity in a positive way (in addition to other mentioned effects or advantages). Vrbka and Rowland (2019) have in the past dealt with the financial health of companies operating in the mining industry in the Czech Republic. Resulting from the cluster analysis, this recommendation should be applied mainly in the countries included in cluster 2, where is a relatively low level of labour productivity and there is still space to increase the FDI inflow, these countries are: Chile, Czech Republic, Estonia, Greece, Hungary, Japan, Korea, Latvia, Lithuania, Mexico, New Zealand, Poland, Portugal, Slovak Republic, Slovenia, and Turkey. Considering this point of view, from these countries, the higher potential can be seen in Mexico, Chile in the first line and in Latvia and Estonia in the second. The recommendations resulting from this study and the effects of FDI on the mining industry can also be supported by the research results of Sun and Anwar (2019), who concluded that foreign investment policy in China needs to be adjusted to attract more FDI to China's iron ore mining industry. From the environmental point of view and the ecology, they highlighted that FDI could help develop mining technologies that are not only more efficient but also create less pollution.

The main risk factors for FDI in the mining sector can be divided into geological, political, regulatory, marketing, fiscal, monetary, environmental and social, operational, and profit (Otto, 1992; Amoatey et al., 2017; Bednarova et al., 2020). Kasych, Rowland and Yakovenko (2019), for example, discussed management tools to support the economic sustainability of companies operating in the mining industry. Other studies also provided management inspiration (Amoah et al., 2021; Bednarova et al., 2009; Belas et al., 2020; Dvorsky et al., 2021; Durana et al., 2021; Halaskova et al., 2021; Ik \& Azeez, 2020; Jurkasova et al., 2016; Mura, 2021; Siwiec et al., 2019). The recommendation for the policymakers in this context is to focus on political and regulatory factors to support the inflow of FDI in the individual countries and thus to help increase the efficiency of the mining sector. Similar insights can be transferred to other areas, which favours this study (Gavurova et al., 2020; Gavurova et al., 2021; Kol'veková et al., 2019; Pimonenko et al., 2021; Stefko et al., 2020; Ivankova et al., 2021; Př́vara et al., 2019). In recent years, some researchers have considered the infrastructure of a host country as a risk factor that affects foreign investment in the mining sector (Tole \& Koop 2011), which could be another important task to deal with in the FDI host countries.

Based on the research performed in this study and on the concluding remarks, the future research recommendation becomes more clear. The future research recommendation proceeds from the main limitations, as the use of macroeconomic indicators for the OECD countries that are not sector-specific, so their results can be applied for the mining sector only with some suspicion. There is a need to collect data, especially on the FDI inflow in the mining sector, but there will also be a need to change the macroeconomic perspective of the rest of the examined variables with a focus on labour productivity. An interesting thing would be to include additional indicators representing the efficiency of the mining sector performance. The research should also be extended to other countries.

\section{References}

Abonyi, J., \& Feil, B. (2007). Cluster Analysis for Data Mining and System Identification (2007th ed.). Birkhäuser Basel.

Adams, S. (2009). Foreign direct investment, domestic investment, and economic growth in Sub-Saharan Africa. Journal of Policy Modeling, 31(6), 939-949. https://doi.org/10.1016/j.jpolmod.2009.03.003

Aitken, B. J., \& Harrison, A. E. (1999). Do Domestic Firms Benefit from Direct Foreign Investment? Evidence from Venezuela. American Economic Review, 89(3), 605-618. https://doi.org/10.1257/aer.89.3.605

Akinlo, A. (2004). Foreign direct investment and growth in Nigeria. Journal of Policy Modeling, 26(5), 627-639. https://doi.org/10.1016/j.jpolmod.2004.04.011

Alfaro, L., Chanda, A., Kalemli-Ozcan, S., \& Sayek, S. (2004). FDI and economic growth: the role of local financial markets. Journal of International Economics, 64(1), 89-112. https://doi.org/10.1016/s00221996(03)00081-3 
Amoah, J., Jibril, A. B., Luki, B. N., Odei, M. A. \& Yawson, C. (2021). Barriers of SMEs' sustainability in SubSaharan Africa: A pls-sem approach. International Journal of Entrepreneurial Knowledge, 9(1), 10-24. https://doi.org/10.37335/ijek.v9i1.129

Amoatey, C. T., Famiyeh, S., \& Andoh, P. (2017). Risk assessment of mining projects in Ghana. Journal of Quality in Maintenance Engineering, 23(1), 22-38. https://doi.org/10.1108/jqme-09-2015-0044

Bačová, M. (2016, November). Direct foreign investment in Slovakia and their impact on selected economic indicators. In P. Krištofík, M. Orviská, \& P. Pisár (Eds.), Investing in Europe - current situation and perspectives. (pp. 1-6). https://www.ef.umb.sk/konferencie/kfu_2016/prispevky.htm

Bacovic, M., Jacimovic, D., Lipovina Bozovic, M., \& Ivanovic, M. (2021). The Balkan Paradox: Are Wages and Labour Productivity Significant Determinants of FDI Inflows? Journal of Balkan and Near Eastern Studies, 23(1), 144-162. https://doi.org/10.1080/19448953.2020.1818039

Bednarova, L., Dzukova, J., Grosos, R., Gomory, M., \& Petras, M. (2020). Legislative instruments and their use in the management of raw materials in the Slovak Republic. Acta Montanistica Slovaca, 25(1), 105-115.

Bednarova, L., Liberko, I., \& Weiss, R. (2009). Benchmarking in firms management. Acta Montanistica Slovaca, 14(1), 86-91.

Belas, J., Amoah, J., Petráková, Z., Kliuchnikava, Y., \& Bilan, Y. (2020). Selected factors of SMEs management in the service sector. Journal of Tourism and Services, 21(11), 129-146. https://doi.org/10.29036/jots.v11i21.215

Biørn, E., \& Han, X. (2017). Revisiting the FDI impact on GDP growth in errors-in-variables models: a panel data GMM analysis allowing for error memory. Empirical Economics, 53(4), 1379-1398. https://doi.org/10.1007/s00181-016-1203-4

Blomström, M., \& Kokko, A. (1998). Multinational corporations and spillovers. Journal of Economic Surveys, 12(3), 247-277. https://doi.org/10.1111/1467-6419.00056

Blomström, M., Kokko, A., \& Mucchielli, J. L. (2003). The economics of foreign direct investment incentives. Foreign Direct Investment in the Real and Financial Sector of Industrial Countries, 37-60. https://doi.org/10.1007/978-3-540-24736-4_3

Boghean, C., \& State, M. (2015). The relation between foreign direct investments (FDI) and labour productivity in the European Union countries. Procedia Economics and Finance, 32, 278-285. https://doi.org/10.1016/s2212-5671(15)01392-1

Borensztein, E., de Gregorio, J., \& Lee, J. W. (1998). How does foreign direct investment affect economic growth? Journal of International Economics, 45(1), 115-135. https://doi.org/10.1016/s0022-1996(97)00033-0

Brandenburger, A., \& Polak, B. (1996). When managers cover their posteriors: Making the decisions the market wants to see. RAND Journal of Economics, 27(3), 523-541. https://doi.org/10.2307/2555842

Brems, H. (1970). A growth model of international direct investment. The American Economic Review, 60(3), 320-331.

Campisi, D., de Nicola, A., Farhadi, M., \& Mancuso, P. (2013). Discovering the impact of ICT, FDI and human capital on GDP: A cross-sectional analysis. International Journal of Engineering Business Management, 5, 46. https://doi.org/10.5772/56922

Capron, L., \& Mitchell, W. (1998). The role of acquisitions in reshaping business capabilities in the international telecommunications industry. Industrial and Corporate Change, 7(4), 715-730. https://doi.org/10.1093/icc/7.4.715

Caves, R. E. (2007). Multinational Enterprise and Economic Analysis (Cambridge Surveys of Economic Literature) (3rd ed.). Cambridge University Press.

Chin, K. R. E. (2016). Foreign direct investment (FDI), trade and its contribution to the mining sector of Guinea. Journal on Innovation and Sustainability, 7(2), 65-71. https://doi.org/10.24212/2179-3565.2016v7i2p6571

Civelek, M., Ključnikov, A., Krajčík, V., \& Žufan, J. (2019). The importance of discount rate and trustfulness of a local currency for the development of local tourism. Journal of Tourism and Services, 10(19), 77-92. https://doi.org/10.29036/jots.v10i19.117

Civelek, M., Gajdka, K., Světlík, J., \& Vavrečka, V. (2020). Differences in the usage of online marketing and social media tools: evidence from Czech, Slovakian and Hungarian SMEs. Equilibrium. Quarterly Journal of Economics and Economic Policy, 15(3), 537-563. https://doi.org/10.24136/eq.2020.024

Civelek, M., Ključnikov, A., Fialova, V., Folvarčná, A., \& Stoch, M. (2021). How innovativeness of family-owned SMEs differ depending on their characteristics? Equilibrium. Quarterly Journal of Economics and Economic Policy, 16(2), 413-428. https://doi.org/10.24136/eq.2021.015

Damijan, J. P., \& Kostevc, C. (2011). Trade liberalisation and economic geography in CEE countries: the role of FDI in the adjustment pattern of regional wages. Post-Communist Economies, 23(02), 163-189. https://doi.org/10.1080/14631377.2011.570041 
Dombi, Á. (2015, December 2). Külföldi Müködötőke-Áramlás (fogalmak, tendenciák, hatások) [Slides]. DocPlayer.Hu. https://docplayer.hu/24538752-Kulfoldi-mukodotoke-aramlas-fogalmak-tendenciakhatasok.html

Dunning, J. H. (1980). Toward an Eclectic Theory of International Production: Some Empirical Tests. Journal of International Business Studies, 11(1), 9-31. https://doi.org/10.1057/palgrave.jibs.8490593

Durana, P., Michalkova, L., Privara, A., Marousek, J., \& Tumpach, M. (2021). Does the life cycle affect earnings management and bankruptcy? Oeconomia Copernicana, 12(2), 425-461. https://doi.org/10.24136/oc.2021.015

Durda, L., \& Ključnikov, A. (2019). Social networks in entrepreneurial startups development. Economics and Sociology, 12(3), 192-208. https://doi.org/10.14254/2071- 789X.2019/12-3/13

Dvorsky, J., Belas, J. Jr., Cera, G., \& Bilan, S. (2021). Disparities in the perception of business risks in connection with the achieved education of the owner/manager and doing business. International Journal of Entrepreneurial Knowledge, 9(1), 25-40. https://doi.org/10.37335/ijek.v9i1.123

Firth, M. (1980). Takeovers, Shareholder Returns, and the Theory of the Firm. The Quarterly Journal of Economics, 94(2), 235-260. https://doi.org/10.2307/1884539

Gavurova, B., Ivankova, V., Rigelsky, M., \& Př́ivarová, M. (2020). Relations between tourism spending and global competitiveness - an empirical study in developed OECD countries. Journal of Tourism and Services, 21(11), 38-54. https://doi.org/10.29036/jots.v11i21.175

Gavurova, B., Rigelsky, M., \& Ivankova, V. (2021). Greenhouse gas emissions and health in the countries of the European Union. Frontiers in Public Health, 9, 756652. https://doi.org/10.3389/fpubh.2021.756652

Girma, S. (2005). Safeguarding Jobs? Acquisition FDI and Employment Dynamics in U.K. Manufacturing. Review of World Economics, 141(1), 165-178. https://doi.org/10.1007/s10290-005-0020-1

Görg, H., \& Strobl, E. (2001). Multinational Companies and Productivity Spillovers: A Meta-Analysis. The Economic Journal, 111(475), F723-F739. https://doi.org/10.1111/1468-0297.00669

Halaskova, M, Halaskova, R., Gavurova, B., \& Kubak, M. (2021). Fiscal decentralisation of services: The case of the local public sector in European countries. Journal of Tourism and Services, 23(12), 26-43. https://doi.org/10.29036/jots.v12i23.234

Halmos, K. (2011). The Effect of FDI, Exports and GDP on Income Inequality in 15 Eastern European Countries. Acta Polytechnika Hungarica, 8(1), 123-136.

Han, X., \& Wei, S. J. (2015). Re-examining the middle-income trap hypothesis: What to reject and what to revive? SSRN Electronic Journal. https://doi.org/10.2139/ssrn.2707454

Haskova, S. \& Volf, P. (2017). The Contribution of Foreign Direct Investments to the Convergence of Regions in the Czech Republic. Littera Scripta, 10(2), 23-33.

IBM Institute for Business Value. (2019). Global Loction Trends: 2019 Annual Report: Trade regulations and digital disruptions affect the economic outlook. (pp. 6). https://www.ibm.com/downloads/cas/R9VW3VO5

Ik, M., \& Azeez, A. A. (2020). Organisational green behavioural change: The role of Change Management. International Journal of Entrepreneurial Knowledge, 8(1), 34-48. https://doi.org/10.37335/ijek.v8i2.98

Imoudu, E. C. (2012). The Impact of Foreign Direct Investment on Nigeria's Economic Growth; 1980-2009: Evidence from the Johansen's Cointegration Approach. International Journal of Business and Social Science, 3(6), 122-34.

Inekwe, J. N. (2013). FDI, Employment and Economic Growth in Nigeria. African Development Review, 25(4), 421-433. https://doi.org/10.1111/1467-8268.12039

Ivankova, V., Gavurova, B., Bačík, R., \& Rigelský, M. (2021). Relationships between road transport infrastructure and tourism spending: A development approach in European OECD countries. Entrepreneurship and Sustainability Issues, 9(2), 535-551. https://doi.org/10.9770/jesi.2021.9.2(35)

Jensen, M. C. (1988). Takeovers: Their Causes and Consequences. Journal of Economic Perspectives, 2(1), 2148. https://doi.org/10.1257/jep.2.1.21

Jurkasova, Z., Cehlar, M., \& Khouri, S. (2016). Tools for organizational changes managing in companies with high qualified employees. Proceedings of International Conference on Engineering Science and Production Management (ESPM), pp. 409-412.

Kasych, A. (2019). Effectiveness of the companies participating in international strategic alliances: methodological and analytical aspects. Littera Scripta, 12(1), 43-61.

Kasych, A., Medvedeva, G. (2019). International technology transfer as a mechanism of activating the innovative development of a country. Littera Scripta, 12(2), 30-48.

Kasych, A., Rowland, Z. \& Yakovenko, Y. (2019). Modern management tools for sustainable development of mining enterprises. In Bondarenko V., Kovalevska I., Cawood F., Hardygora M., Malova O., Lysenko R. E3S Web of Conferences: Ukrainian School of Mining Engineering - 2019. 1. vyd. Les Ulis, France: EDP Sciences, $17 \mathrm{p}$.

Kida, N. M. (2014). Foreign Direct Investment, Environment and Economic Growth. Acta Universitatis Danubius Oeconomica, 10(4), 31-41. 
Ključnikov, A., Popesko, B., Kloudová, J. (2019). Economics of the international ridesharing services - a trap for amateurs. Entrepreneurship and Sustainability Issues, 6(3), 1172-1181. http://doi.org/10.9770/jesi.2019.6.3(8)

Ključnikov, A., Civelek, M., Krajčík, V., \& Ondrejmišková, I. (2020a). Innovative regional development of the structurally disadvantaged industrial region by means of the local currency. Acta Montanistica Slovaca, 25(2). 224-235.

Ključnikov, A., Civelek, M., Polách, J., Mikoláš, Z., \& Banot, M. (2020b). How do security and benefits instill trustworthiness of a digital local currency? Oeconomia Copernicana, 11(3), 433-465. http://doi.org/10.24136/oc.2020.018

Ključnikov, A., Civelek, M., Vozňáková, I., \& Krajčík, V. (2020c). Can discounts expand local and digital currency awareness of individuals depending on their characteristics? Oeconomia Copernicana, 11(2), 239-266. http://doi.org/10.24136/oc.2020.010

Ključnikov, A., Civelek, M., Fialova, V., \& Folvarčná, A. (2021). Organizational, local, and global innovativeness of family-owned SMEs depending on firm-individual level characteristics: evidence from the Czech Republic. Equilibrium. Quarterly Journal of Economics and Economic Policy, 16(1), 169-184. http://doi.org/10.24136/eq.2021.006

Kolková, A., \& Ključnikov, A. (2021). Demand forecasting: an alternative approach based on technical indicator Pbands. Oeconomia Copernicana, 12(4), 863-894. doi: 10.24136/oc.2021.028

Kol’veková, G., Liptáková, E., Štrba, L., Kršák, B., Sidor, C., Cehlár, M., Khouri, S., \& Behún, M. (2019). Regional tourism clustering based on the Three Ps of the sustainability services marketing matrix: An example of Central and Eastern European Countries. Sustainability, 11(2), 400. https://doi.org/10.3390/su11020400

Kosztowniak, A. (2016). Verification of the relationship between FDI and GDP in Poland. Acta Oeconomica, 66(2), 307-332. https://doi.org/10.1556/032.2016.66.2.6

Kottaridi, C., Papanastassiou, M., \& Pitelis, C. N. (2010). MNE subsidiaries, productive opportunity, and the location of innovative activity. In P. Nijkamp \& I. Siedschlag (Eds.), Economic Growth, Innovation and Competitiveness in a Knowledge-Based World Economy (pp. 235-258). Edward Elgar Publishing.

Král', P., Kanderová, M., Kaščáková, A., Nedelová, G., \& Valenčáková, V. (2009). Viacrozmerné štatistické metódy so zameraním na riěsenie problémov ekonomickej praxe. (1st ed.). Univerzita Mateja Bela, Ekonomická fakulta v Banskej Bystrici.

Kumar, S., \& Russell, R. R. (2002). Technological Change, Technological Catch-up, and Capital Deepening: Relative Contributions to Growth and Convergence. American Economic Review, 92(3), 527-548. https://doi.org/10.1257/00028280260136381

Lavickova, M., Kolafova, P. M. \& Turinska, L. (2021). Language courses as tool to motivate employees in South Bohemian enterprises. Littera Scripta, 14(1), 86-106. https://doi.org/10.36708/Littera_Scripta2021/1/8

Li, Y., Zhou, Z., \& Li, Z. (2018). A Study on the Influence of FDI on Wages based on the View of zGeneralised Virtual Economy. Proceedings of the 2018 International Symposium on Social Science and Management Innovation (SSMI 2018), 68, 151-153. https://doi.org/10.2991/ssmi-18.2019.28

Lipsey, R. E., \& Sjöholm, F. (2004). FDI and wage spillovers in Indonesian manufacturing. Review of World Economics, 140(2), 321-332. https://doi.org/10.1007/bf02663651

Macdougall, G. D. A. (2009). The benefits and costs of private investment from abroad: a theoretical approach. Bulletin of the Oxford University Institute of Economics \& Statistics, 22(3), 189-211. https://doi.org/10.1111/j.1468-0084.1960.mp22003002.x

Meixnerová, L., \& Krajňák, M. (2020). Macroeconomic time series affecting the minimum and average wages of V4 countries. E+M Ekonomie a Management, 23(4), 4-22. https://doi.org/10.15240/tul/001/2020-4-001

Meloun, M., Militký, J., \& Hill, M. (2012). Statistická analýza vícerozměrných dat v př́kladech. Academia.

Morck, R., Shleifer, A., \& Vishny, R. W. (1990). Do managerial objectives drive bad acquisitions? The Journal of Finance, 45(1), 31-48. https://doi.org/10.1111/j.1540-6261.1990.tb05079.x

Mura, L., (2021). Internationalization of Slovak family enterprises - territorial approach. International Journal of Entrepreneurial Knowledge, 9(2), 109-118. https://doi.org/10.37335/ijek.v9i2.147

OECD. (2002). Foreign Direct Investment for Development: Maximising benefits, minimising costs (Overview). OECD Publications Service. https://www.oecd.org/investment/investmentfordevelopment/1959815.pdf

Otto, J. M. (1992). Criteria for assessing mineral investment conditions: mineral investment conditions in selected countries of the Asia-Pacific Region. United Nations, New York.

Pimonenko, T., Lyulyov, O., \& Us, Y. (2021). Cointegration between economic, ecological and tourism development. Journal of Tourism and Services, 23(12), 169-180. https://doi.org/10.29036/jots.v12i23.293

Piscitello, L., \& Rabbiosi , L. (2005). The impact of inward FDI on local companies' labour productivity: evidence from the Italian case. International Journal of the Economics of Business, 12(1), 35-51. https://doi.org/10.1080/1357151042000323120 
Přívara, A. (2019). Explaining emigration patterns in Estonia, Lithuania, Slovenia and Slovakia. Geografický časopis, 71(2), 161-180. https://doi.org/10.31577/geogrcas.2019.71.2.09

Přívara, A. (2021). Labour market efficiency and emigration in Slovakia and EU neighbouring countries. Economic Research-Ekonomska Istraživanja, https://doi.org/10.1080/1331677X.2020.1858131

Přívara, A., Rievajová, E., \& Barbulescu, A. (2020). Attracting high skilled individuals in the EU: The Finnish experience. Migration Letters, 17(2), 369-377. https://doi.org/10.33182/ml.v17i2.927

Shleifer, A., \& Vishny, R. W. (1989). Management entrenchment: The case of manager-specific investments. Journal of Financial Economics, 25(1), 123-139. https://doi.org/10.1016/0304-405x(89)90099-8

Siwiec, D., Bednarowa, L., Pacana, A., Zawada, M., \& Rusko, M. (2019). Decision support in the selection of fluorescent penetrants for industrial non-destructive testing. Przemyst Chemiczny, 98(10), 1594-1596. https://doi.org/10.15199/62.2019.10.12

Solow, R. M. (1999). Neoclassical Growth Theory. In Taylor, J. B., \& M. Woodford (Eds.), Handbook of Macroeconomics (Volume 1C) (1st ed.). North Holland.

Stefko, R., Gavurova, B., Ivankova, V., \& Rigelsky, M. (2020). Gender Inequalities in Health and Their Effect on the Economic Prosperity Represented by the GDP of Selected Developed Countries-Empirical Study. International Journal of Environmental Research and Public Health, 17(10), 3555. https://doi.org/10.3390/ijerph17103555

Stigler, G. J. (1964). A theory of oligopoly. Journal of Political Economy, 72(1), 44-61. https://doi.org/10.1086/258853

Sun, S., \& Anwar, S. (2019). R\&D activities and FDI in China's iron ore mining industry. Economic Analysis and Policy, 62, 47-56. https://doi.org/10.1016/j.eap.2019.01.003

Tole, L., \& Koop, G. (2011). Do environmental regulations affect the location decisions of multinational gold mining firms? Journal of Economic Geography, 11(1), 151-177. https://doi.org/10.1093/jeg/lbp064

Virglerova, Z., Conte, F., Amoah, J., \& Massaro, M. R. (2020). The perception of legal risk and its impact on the business of SMEs. International Journal of Entrepreneurial Knowledge, 8(2), 1-13. https://doi.org/10.37335/ijek.v8i2.115

Vrbka, J.\& Rowland, Z. (2019). Assessing of financial health of companies engaged in mining and extraction using methods of complex evaluation of enterprises. In Ashmarina, S., Vochozka, M.. Sustainable Growth and Development of Economic Systems: Contradictions in the Era of Digitalization and Globalization, In: Contributions to Economics. Cham, Switzerland: Springer, 321-333.

Waldkirch, A., Nunnenkamp, P., \& Alatorre Bremont, J. E. (2009). Employment Effects of FDI in Mexico's NonMaquiladora Manufacturing. The Journal of Development Studies, 45(7), 1165-1183. https://doi.org/10.1080/00220380902952340

Wang, S. \& Wei, X. (2017). Relationships between exchange rates, economic growth and FDI in China: An empirical study based on the TVP-VAR model. Littera Scripta, 10(1), 166-179.

Ward, J. H. (1963). Hierarchical Grouping to Optimize an Objective Function. Journal of the American Statistical Association, 58(301), 236-244. https://doi.org/10.1080/01621459.1963.10500845

Žufan, J., Civelek, M., Hamarneh, I., \& Kmeco, L'. (2020). The impacts of firm characteristics on social media usage of SMEs: Evidence from the Czech Republic. International Journal of Entrepreneurial Knowledge, 8(1), 102-113. doi:10.37335/ijek.v8i1.111 